\title{
Cultural and societal obstacles in responding to Swaziland's HIV epidemic
}

$\mathrm{N}$ ew statistics indicate the HIV epidemic in the Kingdom of Swaziland has stabilized in the past five years, but the country still has the highest HIV prevalence in the world.

Phase one of the Swaziland HIV Incidence Measurement Survey indicated that $31 \%$ of adults aged $18-49$ are HIV-positive (www.mailman.columbia .edu/news/first-findings-released-swazil and-hiv-incidence-measurement-survey -announced-croi-2012).

The Swaziland government and numerous outside organizations have worked diligently to decentralize health services, ramp up testing and treating efforts, and shift tasks to new cadres of health workers.

The results hold promise. Today, more than $80 \%$ of the estimated 101000 people in the nation who potentially need antiretrovirals (ARTs) those with a CD4 count of 350 cells $/ \mathrm{mm}^{3}$ or less - are actually getting them.

But rather than counting on these trends to continue, efforts are being focused on getting ARTs to the remaining $20 \%$, and to expand testing to the remaining $60 \%$ of the population who still haven't been tested.

"The priority now," says Minister of Health and Social Welfare Benedict Xaba, "is to mobilize people in communities to go for HIV testing and counselling, making sure to link and enrol them to care and treatment services and lastly, to make sure that they are retained in care and treatment."

The percentage of people on ARTs has "been climbing gently from $65 \%$ in 2007," says Dr. Velephi Okello, national coordinator for ARTs at the country's Ministry of Health. "We want to accelerate now so that by $2014,90 \%$ of those who need ART will have it."

That's an ambitious target, she admits. "Increasing from $80 \%$ to $90 \%$ will be hard. This is a hard-to-reach population - people who aren't coming [for HIV testing] and don't want to.

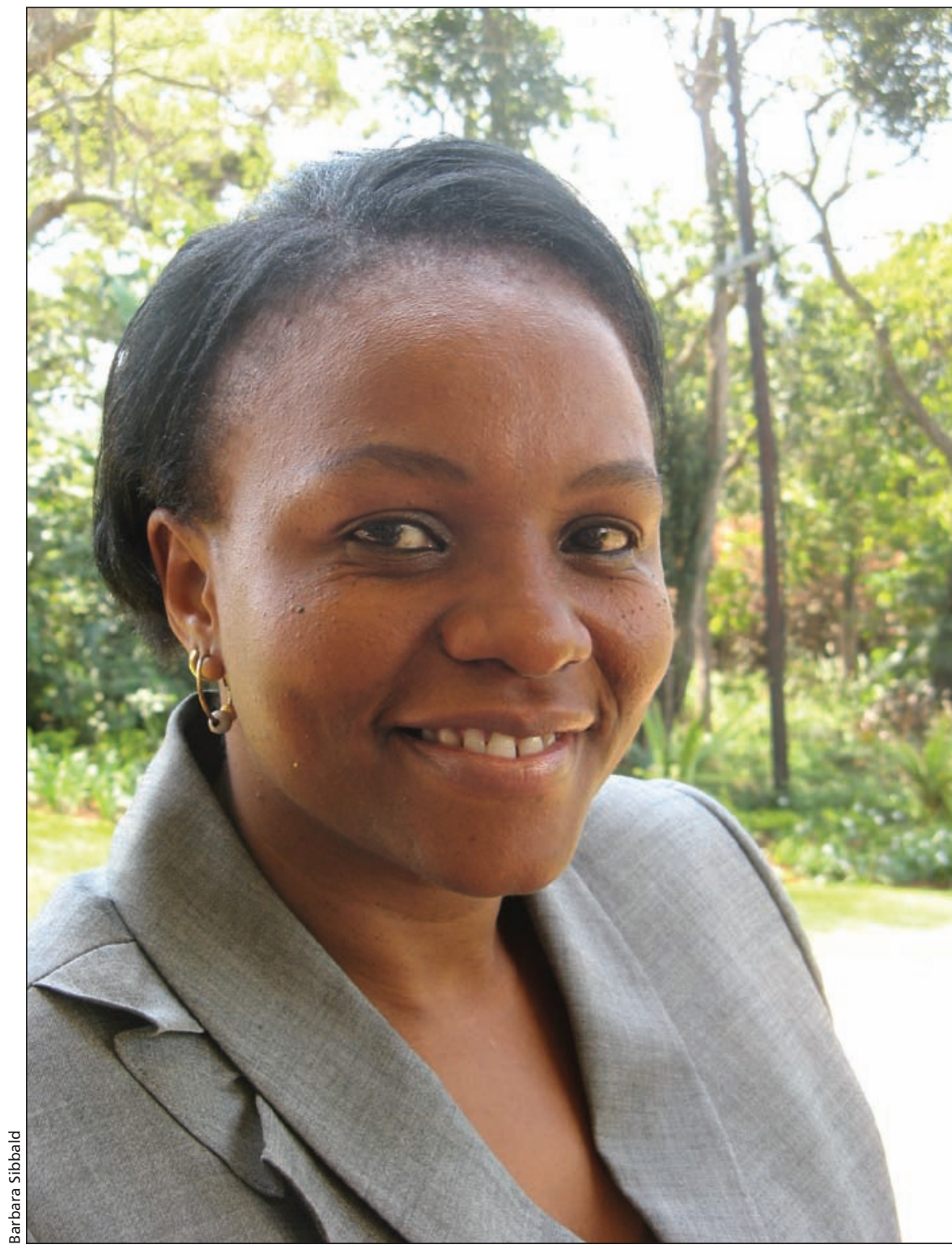

It's a huge challenge to increase the percentage of HIV patients in Swaziland who are on antiretrovirals, says Dr. Velephi Okello, national coordinator for antiretrovirals at the country's Ministry of Health. "We want to accelerate now so that by $2014,90 \%$ of those who need ART will have it."

We'll need to change our messaging ... to mobilize testing and then to get CD4 counts as quickly as possible." Why won't more people go for free testing and free ARTs?

There's no simple answer, but one factor is denial: "People here just don't want to know unless they are sick," says Zanele Zwane, who does advocacy and communications for Médecins Sans Frontières (MSF) in Swaziland. "The majority test late for HIV and TB [tuberculosis]. TB or another infection is often the test trigger." 
Xaba says stigma and fear of discrimination also keep people from accessing HIV services. "We must normalize HIV. Counselling and testing are the entry point for solving the problem in the country. People have to know their HIV status."

Despite the overall stabilization of HIV rates, some subpopulation groups have rates that are higher than previously reported, including $54 \%$ of women aged $30-34$ and $48 \%$ of men aged 35-39.

Women are more likely to know their status than men, according to the HIV incidence report, which was led by the Ministry of Health, supported by the US Centers for Disease Control and Prevention and the International Center for AIDS Programs at Columbia University in New York City. The report urged improved strategies aimed at convincing men to test and treat.

Men are the main challenge, says Xaba. Only $18 \%$ of men test for HIV, compared to $33 \%$ of women, who most often are tested when they are pregnant. "Men enrol late for antiretrovirals, when their CD4s have dropped much lower than the women's," adds Xaba. According to UNAIDS, more than $90 \%$ of women, and just $71 \%$ of men, in Swaziland who needed ART were receiving it in 2011 (www.unaids.org/en /dataanalysis/knowyourresponse/country progressreports/2012countries/ce_SZ _Narrative_Report $\% 5 \mathrm{~b} 1 \% 5 \mathrm{~d}$.pdf).

"There's a need to develop malefriendly services that attract men to the health facilities and break the cultural norms that exist that clinics are meant for women and children," says Xaba, who was trained as a nurse and midwife.

Most men go to traditional healers, of which there are an estimated 8000 in the country, says Xaba. "There's an issue of cultural beliefs. Some people say it's not HIV, it's a traditional disease. There are a lot of myths surrounding it."

Traditional culture must be respected in treatment of sexually transmitted disease and to that end, efforts are being made to effectively address the influ- ence of traditional healers, says Xaba. Village and area chiefs, who hold considerable sway in the Swazi culture, are being educated so they understand the importance of testing.

"When a chief says something, then the people really listen," Xaba says, adding that King Mswati III is fully on board, "which grabs the attention of the chiefs."

The national effort to test and treat more Swazis also includes a program called MaxArt, which is funded by an $€ 8.8$ million contribution from the Netherlands postcode lottery. It aims to achieve a $90 \%$ treatment rate by 2014 and ultimately, a rate of zero new HIV infections, through such tools as pointof-care CD4 testing; nurse-initiated ART; male-focused health days; an appointment reminder system using text messaging to improve retention of individuals in care; an adolescent support initiative; community team identification of barriers to HIV testing among adolescents and men; and strengthened testing and counselling services.

MSF, which is among a host of international organizations involved in the effort, is bringing counselling and testing to male gatherings in Shiselweni, the most impoverished of Swaziland's four regions. Outreach teams travel around in three cars, setting up tents where men gather: the army base, police training facilities, soccer and football pitches, colleges and near the border to South Africa, where many Swazis go to work in the mines. They also set up operations at traditional Swazi events, such as Sidla Inhloko, when a cow is slaughtered and its head, a great delicacy, is prepared and eaten. MSF has also applied for permanent testing sites in places like barbershops, in which they aim to do 1000 HIV tests per month.

"They won't come to us, so we go to them," says Pieterjan Wouda, MSF's field coordinator in Shiselweni. "We've achieved what we can with the clinics. We set up, it's like a circus, seven days a week."

"Ideally, every sexually active adult should be tested," says Wouda. But until that is achieved, MSF will be hoping to gradually increase the number of Swazis who are tested, says Dr. Kiran Jobanputra, a researcher with the international association. "In 2013, we're aiming for 66000 tests in the community and in clinics." - Barbara Sibbald, CMAJ

CMAJ 2013. DOI:10.1503/cmaj.109-4396

Editor's note: Sixth of a multipart series. Barbara Sibbald's accommodation and transportation while in Swaziland were provided by Médecins sans Frontières.

Part I: Making sense of the world's highest HIV rate

(www.cmaj.ca/lookup/doi/10.1503/cmaj.109-4315).

Part II: The face of an epidemic

(www.cmaj.ca/lookup/doi/10.1503/cmaj.109-4320).

Part III: Responding to Swaziland's dual epidemic

(www.cmaj.ca/lookup/doi/10.1503/cmaj.109-4334).

Part IV: New diagnostics, available care offer hope to patients with drug-resistant tuberculosis (www.cmaj.ca/lookup/doi/10.1503/cmaj.109-4341).

Part V: "I never gave up hope"

(www.cmaj.ca/lookup/doi/10.1503/cmaj.109-4369).

Part VII: Suffer the children (www.cmaj.ca/lookup/doi/10.1503/cmaj.109-4404).

For other patient stories, the TB \& Me website features a collection of blogs written by people living with MDR-TB in different parts of the world (http://blogs.msf.org/tb/). 